\title{
HTLV- I INFECTION IS NOT ASSOCIATED WITH A HIGHER RISK OF DEATH IN PERUVIAN HIV-INFECTED PATIENTS
}

Jaime A. COLLINS(1), Adrián V. HERNÁNDEZ(2), José A. HIDALGO(1), Raúl SALAZAR (1) \& the Almenara Hospital AIDS Working Group*

\begin{abstract}
SUMMARY
Limited and contradictory information exists regarding the prognosis of HIV/HTLV-I co-infection. Our goal was to estimate the effect of HTLV-I infection on mortality in HIV-infected patients at a HIV reference center in Peru. We studied a retrospective cohort of HIV-infected patients, who were exposed or unexposed to HTLV-I. Exposed patients were Western Blot (WB) positive for both retroviruses. Unexposed patients were WB positive for HIV, and had least one negative EIA for HTLV-I. These were selected among patients who entered our Program immediately before and after each exposed patient, between January 1990 and June 2004. Survival time was considered between the diagnosis of exposure to HTLV-I and death or censoring. Confounding variables were age, gender, baseline HIV clinical stage, baseline CD4+ T cell count, and antiretroviral therapy. We studied 50 exposed, and 100 unexposed patients. Exposed patients had a shorter survival compared to unexposed patients [median survival: 47 months (95\% CI: 17-77) vs. 85 months (95\% CI: 70-100), unadjusted $p=0.06]$. Exposed patients had a higher rate of mortality compared to unexposed patients (HIV/HTLV-I (24/50 [48\%]) vs. HIV only (37/100 [37\%]), univariable $p=0.2]$. HTLV-I exposure was not associated to a higher risk of death in the adjusted analysis: HR: 1.2 (0.4-3.5). AIDS clinical stage and lack of antiretroviral therapy were associated to a higher risk of dying. In conclusions, HTLV-I infection was not associated with a higher risk of death in Peruvian HIV-infected patients. Advanced HIV infection and lack of antiretroviral therapy may explain the excess of mortality in this population.
\end{abstract}

KEYWORDS: HIV/HTLV-I co-infection; Death; Peru.

\section{INTRODUCTION}

The effect of the infection with the human T-lymphotropic virus type I (HTLV-I) on the progression or survival of human immunodeficiency virus (HIV) infection has not been studied extensively. These effects of the HIV/HTLV-I co-infection remain controversial in spite of an observed strong activation of cytokines that promote HIV infection ${ }^{2,8}$.

Peru is an endemic area for HTLV-I infection. Its presence is well documented, especially in some ethnic groups (e.g. Quechuas, Mestizos, Blacks), and groups with risky sexual behavior (e.g. commercial sex workers $)^{20,23,24}$. HIV/HTLV-I co-infection has previously been reported in Peru, and a shorter survival after onset of clinical acquired immunodeficiency syndrome (AIDS) was described in co-infected men ${ }^{16}$. We aimed to determine the effect of HTLV-I infection on survival of HIVinfected patients from a reference center in Peru, based on a long-term retrospective, observational study, with a larger number of patients than most of the previously published studies.

\section{METHODS}

We performed a retrospective cohort study with HIV-infected patients exposed and unexposed to HTLV-I. Patients were identified from the Almenara General Hospital HIV database, Lima, Peru, between January 1990 and June 2004. All HIV-infected patients were diagnosed with enzyme immunoassay (EIA) (Abbott, USA) and Western Blot tests (DAVIH-Blot, Cuba or Sanofi Pasteur, France). Exposure to HTLV-I was diagnosed with positive EIA (Sanofi Pasteur, France or Abbott, USA) and Western Blot (Cambridge Biotech, USA or DAVIH-Blot, Cuba) tests for HTLV-I. Patients unexposed to HTLV-I had at least one negative result to EIA HTLV-I. The HTLV test was performed at the time of referral to the HIV clinic. Two unexposed patients were selected per each exposed patient. The controls were chosen immediately before and after each exposed patient on our HIV database. All matched controls were chosen within one month of the presentation of the cases. Assuming a proportion of $50 \%$ of exposed patients and $80 \%$ of unexposed patients alive at 48 months $^{6}$, a $20 \%$ of lost to follow-up, an alpha level of 0.05 and a power of $90 \%$, we needed at least to have 43 exposed patients and 86 unexposed patients.

HIV transmission in Peru is mainly by sexual contact, and the intravenous-drug transmission is rare ${ }^{19}$. None of our patients had history of intravenous drug use. HCV prevalence in Peru is low in both the general population ${ }^{14}$ and risk groups, such as HIV patients ( $4 \%$ in our institution,

(1)HIV/AIDS Unit, Department of Internal Medicine, Guillermo Almenara General Hospital, Lima, Peru.

(2)Department of Quantitative Health Sciences, Lerner Research Institute, Cleveland Clinic Foundation, Cleveland, Ohio, USA

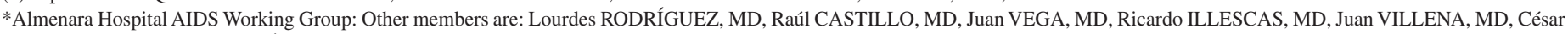
SOTELO, MD, Luis GUTIÉRREZ, MD.

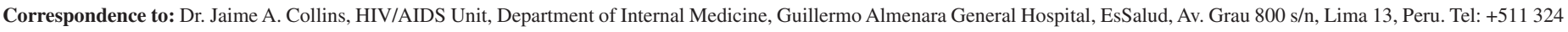
2983- Ext. 4082, Fax: + 511473 0956, E-mail: jcollinslp@ hotmail.com. 
COLLINS, J.A.; HERNÁNDEZ, A.V.; HIDALGO, J.A.; SALAZAR, R. \& ALMENARA HOSPITAL AIDS WORKING GROUP - HTLV-I infection is not associated with a higher risk of death in Peruvian HIV-infected patients. Rev. Inst. Med. trop. S. Paulo, 51(4): 197-201, 2009.

Raul Castillo, unpublished data), and health workers ${ }^{10}$. Therefore we did not include the HCV status in our analysis.

Survival time was considered from the time of referral for both the exposed and unexposed groups until death/censoring or date of the study end (i.e. October 31, 2004). We included other characteristics as confounding variables: age, gender, baseline HIV clinical stage ${ }^{1}$, baseline CD4+ T cell count, and history of antiretroviral therapy. Data regarding age, HIV clinical stage and CD4+ T cell count were recorded at the moment of serological evidence of HTLV-I infection. We did not have information about the time of HIV or HTLV-I seroconversion. Further, we did not include information on HIV viral load because half of the patients were seen when viral load was not commercially available (i.e. first half of the study period). All included patients had the same probability to receive highly active antiretroviral therapy (HAART) according to clinical stage, CD4+ T cell count and viral load. However, some patients were already receiving HAART. For these cases, we considered a CD4+ T cell count prior to initiation of HAART. Antiretroviral therapy categories were: no HAART (no antiretroviral therapy or HAART $<3$ months) and HAART $>3$ months.

We used the $\mathrm{X}^{2}$ or Fisher exact tests for comparison of categorical variables, and Student's t test for continuous variables (2-sided $p$ values). Survival analysis was performed with the Kaplan-Meier method. A univariable Cox proportional hazards model was used to evaluate the independent effect of each variable (age, gender, baseline HIV clinical stage, baseline CD4+ T cell count, and history of antiretroviral therapy) on survival. We then evaluated the independent effect of HTLV-I infection on survival after adjustment for confounding variables. Statistical analyses were performed using SPSS for Windows, version 11.0. Sample size calculation was performed with the NCSS-PASS 2007 software (NCSS, Kaysville, Utah, USA)

\section{RESULTS}

During the period between January 1990 and June 2004, a total of $1456 \mathrm{HIV}$-infected patients were tested for HTLV infection with EIA, and 92 patients $(6 \%)$ were HTLV-I/II positive. From this group, available WB tests revealed HTLV-I co-infection in 68 patients $(5 \%)$ and HTLV-II co-infection in one patient. Of these 68 patients with HIV/HTLV-I co-infection, 50 were available for analysis. The patient with HIV/HTLV-II co-infection was excluded of the study. One hundred HIV-infected patients unexposed to HTLV were selected as comparison group.

The characteristics of exposed and unexposed HIV-positive patients to HTLV-I are shown in Table 1. Exposed patients had a significant higher proportion of males ( $92 \%$ vs. $75 \%, p=0.01$ ), and were older than unexposed patients (mean age: 46 vs. 38 years, $p<0.001$ ). No differences were observed between groups in baseline CD4+ T cell count, baseline HIV clinical stage, and antiretroviral therapy. The comparison of CD4+ T cell count was done with $50 \%(n=19)$ and $72 \%(n=49)$ of exposed and unexposed patients, respectively.

The median survival for the entire cohort was 84 months (95\% CI: 76$92)$, and the survival probability at five years of follow-up was $62 \%$ (42\% exposed, $70 \%$ unexposed). Median survival for exposed and unexposed patients were 47 months (17-77), and 85 months (70-100), respectively
Table 1

Characteristics of HIV-infected patients with or without HTLV-I co-infection

\begin{tabular}{|c|c|c|c|c|}
\hline \multirow[b]{2}{*}{ Variable } & \multicolumn{4}{|c|}{ HIV/HTLV-I co-infection } \\
\hline & $\begin{array}{c}\text { Yes } \\
(n=50)\end{array}$ & $\begin{array}{c}\text { No } \\
(\mathrm{n}=100)\end{array}$ & $\begin{array}{c}\text { Total } \\
(\mathrm{n}=150)\end{array}$ & $p$ values \\
\hline \multicolumn{5}{|l|}{ Age (years) } \\
\hline Mean (SD) & $46(12)$ & $38(10)$ & $41(11)$ & $<0.001$ \\
\hline \multicolumn{5}{|c|}{ CD4+ T cell $($ cell $/ \mu \mathrm{L})$} \\
\hline Mean (SD) & $130(123)$ & $135(137)$ & $134(133)$ & 0.9 \\
\hline \multicolumn{5}{|l|}{ Gender (n, \%) } \\
\hline Male & $46(92)$ & $75(75)$ & $121(87)$ & 0.01 \\
\hline \multicolumn{5}{|c|}{ HIV clinical stage (n, \%) } \\
\hline AIDS & $28(56)$ & $47(47)$ & $75(50)$ & 0.3 \\
\hline No AIDS & $16(32)$ & $45(45)$ & $61(41)$ & \\
\hline Not available & $6(12)$ & $8(8)$ & $14(9)$ & \\
\hline \multicolumn{5}{|c|}{ Antiretroviral therapy $(\mathrm{n}, \%)$} \\
\hline HAART & $22(44)$ & $53(53)$ & $75(50)$ & 0.5 \\
\hline No HAART & $24(48)$ & $38(38)$ & $62(41)$ & \\
\hline Not available & $4(8)$ & $9(9)$ & $13(9)$ & \\
\hline
\end{tabular}

SD: Standard Deviation

(unadjusted $p=0.06$ ). Exposed patients had a higher rate of mortality compared to unexposed patients (HIV/HTLV-I (24/50 [48\%]) vs. HIV only $(37 / 100[37 \%])$, univariable $p=0.2)$. In patients without AIDS at baseline $(\mathrm{n}=75)$, HIV/HTLV-I co-infected patients died more frequently and had higher proportion of cryptococcosis, wasting syndrome and toxoplasmosis than HIV infected patients, although differences were not significant ( $p>0.05$ for all comparisons) (Table 2). However, the proportion of pneumocystosis, tuberculosis and systemic Non-Hodgkin lymphoma was higher in the HIV alone group. Causes of death could not be identified because these were not specified in the clinical records. All deaths occurred at the beginning of the 1990s.

Table 2

Progression to death or first indicator condition of AIDS in HIV patients without AIDS at baseline

\begin{tabular}{lcccc}
\hline Condition & \multicolumn{3}{l}{ HIV/HTLV-I $(\mathrm{n}=22)$} & HIV alone $(\mathrm{n}=53)$ \\
\cline { 2 - 5 } & $\mathrm{N}$ & $\%$ & $\mathrm{~N}$ & $\%$ \\
\hline Death & 7 & 32 & 7 & 13 \\
Cryptococcosis & 2 & 9 & 2 & 4 \\
Wasting syndrome & 2 & 9 & 3 & 6 \\
Toxoplasmosis & 1 & 5 & 0 & 0 \\
Pneumocystosis & 0 & 0 & 2 & 4 \\
Tuberculosis & 0 & 0 & 8 & 15 \\
sNHL & 0 & 0 & 1 & 2 \\
\hline
\end{tabular}

We included six patients in the HIV/HTLV-I group and eight patients in the HIV alone group whose HIV clinical stage was not available; sNHL: Systemic Non-Hodgkin Lymphoma; $p>0.05$ for all comparisons between HIV/HTLV-I and HIV alone groups. 
COLLINS, J.A.; HERNÁNDEZ, A.V.; HIDALGO, J.A.; SALAZAR, R. \& ALMENARA HOSPITAL AIDS WORKING GROUP - HTLV-I infection is not associated with a higher risk of death in Peruvian HIV-infected patients. Rev. Inst. Med. trop. S. Paulo, 51(4): 197-201, 2009.

In the univariable analysis, HIV patients with the HTLV-I infection had a higher risk of death in comparison to patients without the HTLV-I infection (HR 1.6; 95\% CI 1.0-2.8; $p=0.06$ ). Age $>40$ years, CD4+ $<$ $100 \mathrm{cell} / \mu \mathrm{L}, \mathrm{AIDS}$, and no HAART were also directly associated with death (Table 3). Male gender was not associated with death (HR 1.7; $0.8-3.6)$. In multivariable analysis, HTLV-I exposure was not associated with death (HR 1.2; 0.4-3.6). Figure 1 shows the adjusted survival curves for the HIV/HTLV-I and HIV alone groups from the Cox analysis. As expected, AIDS stage and lack of HAART were independently associated with death. There was no effect modification of HIV/HTLV-I co-infection on mortality according to HAART treatment $(p$ for interaction $=0.3$ ).

Table 3

Unadjusted and adjusted effect of HTLV-I exposure on the risk of death in HIVinfected patients

\begin{tabular}{|c|c|c|c|c|c|}
\hline \multirow{2}{*}{ Variable } & \multirow{2}{*}{$\mathrm{n}$} & \multicolumn{2}{|c|}{ Unadjusted } & \multicolumn{2}{|c|}{ Adjusted } \\
\hline & & HR & $95 \% \mathrm{CI} \%$ & HR & $95 \% \mathrm{CI}$ \\
\hline \multicolumn{6}{|c|}{ HIV / HTLV-I exposure } \\
\hline Yes & 50 & 1.6 & $1.0-2.8$ & 1.2 & $0.4-3.6$ \\
\hline No & 100 & & & & \\
\hline \multicolumn{6}{|c|}{ Age (years) } \\
\hline$>40$ & 68 & 1.8 & $1.1-3.0$ & 1.2 & $0.4-3.2$ \\
\hline$<40$ & 82 & & & & \\
\hline \multicolumn{6}{|l|}{ Gender } \\
\hline Male & 121 & 1.7 & $0.8-3.6$ & 1.4 & $0.4-4.6$ \\
\hline Female & 29 & & & & \\
\hline \multicolumn{6}{|c|}{ CD4+ T cell $($ cell $/ \mu \mathrm{L})$} \\
\hline$<100$ & 55 & 3.8 & $1.4-10.2$ & 2.2 & $0.6-8.5$ \\
\hline$>100$ & 45 & & & & \\
\hline \multicolumn{6}{|l|}{ AIDS } \\
\hline Yes & 75 & 5.7 & $2.5-13.1$ & 13.5 & $1.4-132.3$ \\
\hline No & 61 & & & & \\
\hline \multicolumn{6}{|l|}{ HAART } \\
\hline No & 62 & 22.9 & $8.2-64.1$ & 96.5 & $17.0-546.3$ \\
\hline Yes & 75 & & & & \\
\hline
\end{tabular}

Within the group of patients with confirmed HIV/HTLV-I coinfection, we did not find cases of clinical conditions associated to HTLV-I.

\section{DISCUSSION}

HTLV-I infection was not associated with a higher risk of death in Peruvian HIV patients in comparison to patients with HIV infection alone, after adjustment for the main confounding variables. Information from medical records for up to 14 years of follow up was reviewed. Advanced HIV infection and lack of antiretroviral therapy may partly explain the excess of mortality on co-infected HIV/HTLV-I patients. Age was not associated with higher mortality rate.

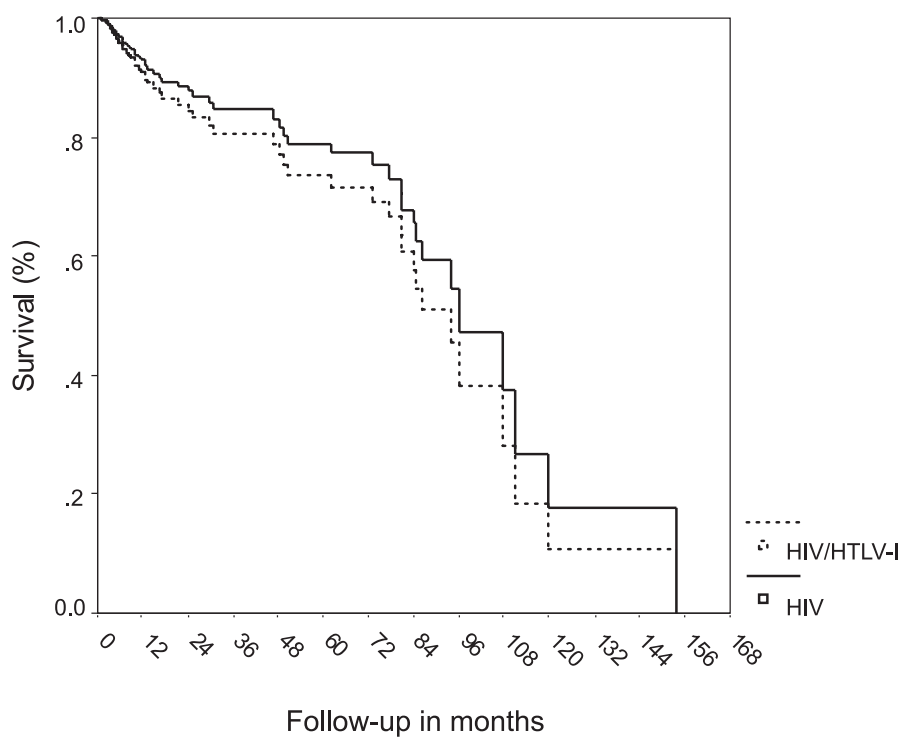

Fig. 1 - Survival by co-infection adjusted for age, gender, CD4+ T cells, AIDS stage and use of HAART

Several retrospective studies have evaluated the effect of HTLV-I infection on survival of HIV patients $4,6,12,16,18,22$. Most of them suggested that HIV/HTLV-I co-infection shortens the survival of these patients $\mathrm{s}^{6,12,16,18,22}$. In contrast, a recent longitudinal retrospective study showed that the HTLV-I infection in persons with HIV was not associated with a shorter survival ${ }^{4}$.

As it has been discussed ${ }^{2,4,7}$, incomplete demographic, laboratory and treatment data, lack of differentiation between HTLV-I and HTLVII $^{12,16,18}$, and the lack of adjustment for confounding variables ${ }^{6,16}$ are key elements that make difficult the interpretation of the effect of HTLV-I on the survival of HIV patients. Moreover, special populations (e.g. intravenous drug users $)^{18}$, and survival after onset of clinical AIDS ${ }^{16,22}$ were considered in these reports.

Further discrepancies between older and newer studies may be related to the use of HAART, because the proper therapy for HIV infection could mask the potentially additive effects of HIV/HTLV-I co-infection on disease progression ${ }^{7}$. However, we could not demonstrate this hypothesis. There was no effect modification on the effect of HIV/HTLV-I co-infection on mortality according to HAART treatment ( $p$ for interaction $=0.3$ ). On the other hand, HAART has little impact on HTLV-I/II genome expression and this can increase the risk of developing neurological disease in HIV/ HTLV-I/II co-infected patients beginning HAART ${ }^{8}$.

The absence of retroviral co-infection effect on survival in our study may be also related to the absence of clinical manifestations or syndromes associated with HTLV-I. This could be explained by the small size of the sample. In any case, this does not support the notion that HIV worsens the clinical presentation of HTLV-I, although there are some case reports suggesting this ${ }^{9,15}$.

It is not clear whether the way of retroviral transmission (sexual vs. intravenous drug use) is related with HIV/HTLV-I co-infection progression. We cannot perform this analysis because almost all of our 
COLLINS, J.A.; HERNÁNDEZ, A.V.; HIDALGO, J.A.; SALAZAR, R. \& ALMENARA HOSPITAL AIDS WORKING GROUP - HTLV-I infection is not associated with a higher risk of death in Peruvian HIV-infected patients. Rev. Inst. Med. trop. S. Paulo, 51(4): 197-201, 2009

patients acquired retroviral co-infection through sexual transmission, the usual mode of HIV transmission in Peru ${ }^{19}$.

On the other hand, SCHECHTER et al. ${ }^{21}$ reported high CD4+ T cell counts in HIV/HTLV-I co-infected patients in comparison with HIV infected patients. In addition, case reports ${ }^{11,13,17}$ or small case series ${ }^{3}$ have described an accelerated progression to AIDS or the development of AIDS with this immunologic profile. In contrast, BESSINGER et al. ${ }^{5}$ did not find an association between HIV/HTLV-I co-infection and high CD4+ T cell counts. Moreover, a recent large longitudinal study ${ }^{4}$ showed that there were no significant differences in the presence of opportunistic infections, progression to AIDS or death between HIV/ HTLV-I co-infected and HIV infected patients.

To gain some additional insight on the effect of the co-infection on progression of HIV, we compared HIV/HTLV-I and HIV patients diagnosed prior to the development of AIDS. The number of deaths and AIDS-defining conditions did not show significant differences (Table 2). Although the numbers are small, this finding is consistent with the report by BEILKE et al. ${ }^{4}$ and with our observation for the complete population.

Our study has several limitations. First, dates of seroconversion were usually imprecise or unknown, so we were not able to identify true survival times. Second, the sample size is relatively small to reach definite conclusions on the effect of HTLV-I on survival of HIV patients. Third, $26 \%$ of patients were excluded from the final analysis due to missing data on survival. Fourth, few confounding variables had a moderate amount of missing values (up to 33\%), such as baseline CD4+ T cell count, baseline HIV clinical stage, and antiretroviral therapy. However, the overall study period reached 14 years of observation, longer than prior reports. Most of our patients received regular care for prolonged periods of time improving the quality of the information obtained, thus reducing the probability of information bias.

In conclusion, Peruvian patients with HIV/HTLV-I co-infection did not have higher risk of death than patients with HIV infection alone in the long term, after adjusting for the main confounding variables. HAART did not modify the effect of HIV/HTLV-I co-infection on mortality. Prospective cohorts with large number of patients may clarify the effect of HIV/HTLV-I co-infection on mortality.

\section{RESUMO}

\section{A infecção pelo HTLV- I não está associada a maior risco de morte em pacientes peruanos infectados pelo HIV}

Existe informação limitada e contraditória sobre o prognóstico da coinfecção pelo Vírus da Imunodeficiência Humana Tipo 1 (HIV-1) e Vírus Linfotrópico de Células T Humanas Tipo I (HTLV-I). Nosso objetivo foi estimar o efeito da infecção pelo HTLV-I na mortalidade de pacientes infectados pelo HIV-1 em Centro de Referência de HIV no Peru. Trata-se de uma coorte retrospectiva de pacientes infectados pelo HIV, expostos ou não expostos ao HTLV-I. Os pacientes expostos tiveram resultados positivos no Western Blot (WB) para ambos retrovírus. Os pacientes não expostos tiveram resultados positivos para o HIV-1 e pelo menos um teste de EIA negativo para o HTLV-I. Esses pacientes foram selecionados entre aqueles que entraram no nosso Programa imediatamente antes ou depois de cada paciente exposto, no período de janeiro de 1990 a junho de 2004. O tempo de sobrevida foi considerado entre o diagnóstico da exposição ao HTLV-I e a morte. As variáveis de confusão foram: idade, gênero, estágio clínico basal da infecção pelo HIV-1, contagem basal de células CD4, e terapia anti-retroviral. Estudamos 50 pacientes expostos e 100 não expostos. Os pacientes expostos tiveram menor sobrevida quando comparados aos não expostos [mediana de sobrevida: 47 meses (95\% IC: $17-77)$ versus 85 meses (70-100), $p$ não ajustado < 0.06]. Os pacientes expostos tiveram maior risco de morte quando comparados aos não expostos (HIV-1/HTLV-I (24/50 [48\%]) versus HIV-1 só (37/100 [37\%]) $p$ univariado $=0.2$ ). A exposição ao HTLV-I não foi associada a maior risco de morte na análise ajustada: HR: 1.2 (0.4-3.5). O estágio clínico da infecção pelo HIV-1 e a ausência de terapia anti-retroviral foram associados a maior risco de morte. Em conclusão, a infecção pelo HTLV-I não foi associada a maior risco de morte em pacientes peruanos infectados pelo HIV-1. A infecção avançada pelo HIV-1 e a falta de terapia anti-retroviral podem explicar o excesso de mortalidade nesta população.

\section{ACKNOWLEDGMENTS}

The authors are grateful to Dr. E. Celis, Dr. R. Ramirez, and their laboratory staff at G. Almenara Hospital for their assistance in serological studies. Dr. Adrián V. Hernández was supported by a grant from the Netherlands Organization for Scientific Research (ZON/MW 908-02-117).

\section{DECLARATION OF COMPETING INTERESTS}

The authors declare that they have no competing interests.

\section{REFERENCES}

1. ANONYMOUS - 1993 revised classification system for HIV infection and expanded surveillance case definition for AIDS among adolescents and adults. MMWR, 41: RR-17, 1992.

2. ARAUJO, A.; SHEEHY, N.; TAKAHASHI, H. \& HALL, W.W. - Concomitant infections with HIV-1 and HTLV types 1 and 2. In: BROGDEN, K.A. \& GUTHMILLER, J.M., ed. Polymicrobial diseases. Washington, ASM Press, 2002. p. 75-97.

3. BARTHOlOMEW, C.; BLATTNER, W. \& CLEGHORN, F. - Progression to AIDS in homosexual men co-infected with HIV and HTLV-I in Trinidad. Lancet, 2(8573): $1469,1987$.

4. BEILKE, M.A.; THEALL, K.P.; O`BRIEN, M. et al. - Clinical outcome and disease progression among patients coinfected with HIV and human T lymphotropic virus types 1 and 2. Clin. infect. Dis., 39: 256-263, 2004

5. BESSINGER, R.; BEILKE, M.; KISSINGER, P.; JARROTT, C. \& TABAK, O.F. Retroviral coinfections at a New Orleans HIV outpatient clinic. J. acquir. immune defic. Syndr. hum. Retrovirol., 14: 67-71, 1997.

6. BRITES, C.; ALENCAR, R.; GUSMÃO, R. et al. - Co-infection with HTLV-1 is associated with shorter survival time for HIV-1 infected patients in Bahia, Brazil. AIDS, 15: 2053-2055, 2001.

7. BRITES, C.; OLIVEIRA, A.S. \& NETTO, E.M. - Coinfection with HIV and human T lymphotropic virus type 1: what is the real impact on HIV disease? Clin. infect. Dis., 40: $329-331,2005$

8. CASOLI, C.; PILOTTI, E. \& BERTAZZONI, U. - Molecular and cellular interactions of HIV-1/HTLV coinfection and impact on AIDS progression. AIDS Rev., 9: 140-149, 2007. 
COLLINS, J.A.; HERNÁNDEZ, A.V.; HIDALGO, J.A.; SALAZAR, R. \& ALMENARA HOSPITAL AIDS WORKING GROUP - HTLV-I infection is not associated with a higher risk of death in Peruvian HIV-infected patients. Rev. Inst. Med. trop. S. Paulo, 51(4): 197-201, 2009.

9. CASSEB, J.; HONG, M.A.; SALOMÃO, S. et al. - Coinfection with HIV and HTLV-I: reciprocal activation with clinical and immunologic consequences. Clin. infect. Dis., 25: 1259-1260, 1997

10. COLICHON, A.; FIGUEROA, R.; MORENO, A. et al. - Prevalencia serológica de anticuerpos al virus de la hepatitis C en personal de salud en el Perú. Rev. Gastroent. Perú, 24: 13-20, 2004

11. DAISLEY, H.; CHARLES, W.P. \& SWANSTON, W. - Role of HTLV-I co-infection in the AIDS epidemic in the Caribbean: a cause for concern. Int. J. STD AIDS, 10 487-489, 1999

12. ETZEL, A.; SHIBATA, G.Y.; CASEIRO, M.M. \& SEGURADO, A.C. - HTLV-I and HTLV-II co-infections are predictors of shorter survival in a Brazilian HIV seroprevalent cohort. In: PROCEEDINGS OF THE XV INTERNATIONAL AIDS CONFERENCE, Bangkok, Thailand, 2004. Abstracts. MoPeC3382.

13. FANTRY, L.; DE JORGE, E.; AUWAERTER, P.G. \& LEDERMAN, H.M. Immunodeficiency and elevated CD4 T lymphocyte counts in two patients co-infected with HIV and HTLV-I. Clin. infect. Dis., 21: 1466-1468, 1995.

14. FARFAN, G. \& CABEZAS, C. - Prevalencia de la hepatitis viral C en donantes de sangre del Perú. Rev. Gastroent. Perú, 23:171-176, 2003.

15. GOORNEY, B.P. \& YOUNG, A.C. - HIV and HTLV-I co-infection. Int. J. STD AIDS, 11: $205-206,2000$

16. GOTUZZO, E.; ESCAMILLA, J.; PHILLIPS, I.A. et al. - The impact of HTLV type I/II infection on the prognosis of sexually acquired cases of AIDS. Arch. intern. Med. 152: $1429-1432,1992$
17. NADLER, J.P.; BACH, M.C. \& GODOFSKY, E. - Management of coinfection with HIV and HTLV-I. Clin. infect. Dis., 23: 415, 1996.

18. PAGE, J.; LAI, S.; CHITWOOD, D.D. et al. - HTLV I/II seropositivity and death from AIDS among HIV-1 seropositive intravenous drug users. Lancet, 335(8711): 1439 1441,1990

19. PERUVIAN MINISTRY OF HEALTH. General Office of Epidemiology - Situation of HIV/AIDS in Peru (In Spanish). Monthly Epidem. Bull. (Lima), April 2005.

20. SANCHEZ-PALACIOS, C.; GOTUZZO, E.; VANDAMME, A.M. \& MALDONADO Y. - Seroprevalence and risk factors for HTLV-I infection among ethnically and geographically diverse Peruvian women. Int. J. infect. Dis., 7: 132-137, 2003.

21. SCHECHTER, M.; MOULTON, L.H. \& HARRISON, L.H. - HIV viral load and CD4+ lymphocyte counts in subjects coinfected with HTLV-I and HIV-1. J. acquir. immune Defic. Syndr. hum. Retrovirol., 15: 308-311, 1997.

22. SOBESKY, M.; COUPPIE, P; PRADINAUD. R. et al - Co-infection par VIH et HTLV-I et survie au stade SIDA. Presse méd., 29: 413-416, 2000.

23. TRUJILLO, L.; MUNOZ, D.; GOTUZZO, E.; YI, A. \& WATTS, D.M. - Sexual practices and prevalence of HIV, HTLV-I/II, and Treponema pallidum among clandestine female sex workers in Lima, Peru. Sex. transm. Dis., 26: 115-118, 1999.

24. WIGNALL, F.S.; HYAMS, K.C.; PHILLIPS, I.A. et al. - Sexual transmission of HTLV-I in Peruvian prostitutes. J. med Virol., 38: 44-48, 1992.

Received: 01 January 2009

Accepted: 6 May 2009 